\title{
A Prospective Study of Bacterial and Fungal Keratitis in a Tertiary Care Medical College Hospital in Kerala
}

\author{
Dr Shreeram Astic Deshpande*, Dr. Chithira K G, Mr. Faisal K. A. \\ Associate Professor, Department of Microbiology, P.K. Das Institute of Medical Sciences, Vaniamkulam, \\ Kerala
}

*Corresponding Author: Dr Shreeram Astic Deshpande, Associate Professor, Department of Microbiology, P.K. Das Institute of Medical Sciences, Vaniamkulam, Kerala

\begin{abstract}
:
Purpose: To identify the microbial pathogens responsible for traumatic microbial keratitis in a tertiary care hospital.

Methods: All patients with traumatic keratitis from February 2020 - August 2020 were evaluated. The patients were examined by slit-lamp and corneal scrappings were performed for $\mathrm{KOH}$, Gram stain and culture.

Results: In the six-month period 282 cases were examined of which 208 (73.7\%) cases had history of trauma. Of the 208 cases 40 were bacteria, 130 were fungi, 28 had no growth. Fusarium was the most common fungi isolated (n-41, 45.5\%) and Pseudomonas aeruginosa was the most common bacteria isolated (n-9. 22.5\%) revealing fungi as the predominant cause of traumatic corneal ulcer which is different from other studies were Streptococcus pneumoniae was the most common pathogen.
\end{abstract}

Conclusion: This study is important in knowing the changing trends in the pattern of microorganisms causing traumatic corneal ulcer.

Keywords: Microbial keratitis, KOH, Gram stain, Pseudomonas, Fusarium

\section{INTRODUCTION}

Blindness continues to be one of the major public health problems in developing countries. Cataract and corneal diseases are the major cause of blindness in countries with less developed economics. ${ }^{[1]}$ Almost any microorganism can invade the corneal stroma if the normal corneal defense mechanisms i.e. lids, tear film and corneal epithelium are compromised. ${ }^{[2]}$ A wide proper understanding of the etiology by sequential methods, may guide the ophthalmologist in starting specific antimicrobial treatment. The majority of bacteria cultured from infections of cornea are of the same species that normally are present in the conjunctival sac, on the lids or periocular skin, and in the adjacent nasal passages. Their incidence may vary. ${ }^{[5-7]}$

Since, very few studies are present with regards to the etiology of traumatic corneal ulcer, this study was conducted to find out the various bacterial and fungal organisms that are responsible for traumatic corneal ulcers in a tertiary care hospital.

\section{MATERIALS AND METHODS}

The study was a prospective cross sectional study conducted in P.K, Das Institute of Medical Sciences, Vaniamkulam, Kerala, over a period of 6 months from February 2020 - August 2020. All patients with history suggestive of corneal ulcer were subjected to detailed history and clinical examination, and slit lamp examination by ophthalmologist using $4 \%$ xylocaine, by No 15 sterile Bard parker blade. The samples were collected from the bleeding edge and base of each ulcer. The samples were directly inoculated in to sheep blood agar, Mac Conkey agar, Chocolate agar and in Sabourauds dextrose agar. The material obtained from next scraping was spread to labelled slides for $10 \% \mathrm{KOH}$ wet mount and for Gram stain. The bacterial cultures were incubated at $37^{\circ} \mathrm{C}$ for 24 hours and negative cultures at 48 hours and discarded if no growth. The fungal cultures were incubated at $22^{\circ} \mathrm{Cand}$ examined daily and discarded if no growth at end of three weeks. 


\section{RESULTS}

A total of 282 clinical samples were obtained from the patients presenting with history of corneal ulcer of which 208 cases had history of trauma. Of the 208 cases of traumatic corneal ulcer the number of bacteria was 40(19.2\%), fungi (62.5\%), mixed bacteria and fungi $10(4 \%)$ and negative for both bacteria and fungi was $28(13.4 \%)$. Out of the 40 bacterial isolates 12 were Gram positive cocci, 4 were gram positive bacilli, 8 were Gram negative cocci and 16 were gram negative bacilli. The Gram positive cocci included 6 cases (15\%) Streptococcus pneumoniae, 4 cases $(11.4 \%)$ of Staphylococcus aureus and 2 cases $(5.5 \%)$ of Staphylococcus epidermidis. The Gram positive bacilli comprised only 4 cases $(10 \%)$ of Corynebacterium. The Gram negative cocci showed 5 cases (12.5\%) of Moraxella cattarhalis and 3 cases of Neisseria (7.5\%). The Gram negative bacilli was 9 cases of Pseudomonas aeruginosa (22.5\%), 1 case of Enterobacter (2.5\%), 3 case of Klebsiella (7.5\%), 1 case of Escherichia coli $(2.5 \%)$ and 2 cases of Proteus (5\%).

Among the fungal isolates $\mathrm{KOH}$ showed septate hyphae in 90 cases which on culture were 10 cases $(11.1 \%)$ of Penicillium marneffei, 39 cases (49.3\%) of Aspergillus of which $12(30.7 \%)$ were A.fumigatus, $20(51.2 \%)$ were A.flavus, 7 (17.9\%) were A.flavus and 41 cases (45.5\%) of Fusarium. $\mathrm{KOH}$ showed non-septate hyphae in 40 cases which included 18 cases (45\%) of Rhizopus, 12 cases (30\%) of Mucor, 4 cases (10\%) of Absidia and 6 cases (15\%) Curvularia.

Cases of corneal ulcer patients: 282

Cases of Traumatic corneal ulcer: 208 (73.7\%)

Table1. Percentage of various isolates

\begin{tabular}{|l|l|l|l|}
\hline \multicolumn{1}{|c|}{ S.No. } & \multicolumn{1}{c|}{ Isolates } & \multicolumn{1}{c|}{ Number } & \multicolumn{1}{c|}{ Percentage } \\
\hline 1. & Bacterial & 40 & $19.2 \%$ \\
\hline 2. & Fungal & 130 & $62.5 \%$ \\
\hline 3. & Mixed & 10 & $4 \%$ \\
\hline 4 & Negative & 28 & $13.4 \%$ \\
\hline
\end{tabular}

Table2. Distribution of various fungal isolates

\begin{tabular}{|l|l|l|l|l|}
\hline \multicolumn{1}{|c|}{ S.No. } & \multicolumn{1}{c|}{ Septate } & \multicolumn{1}{c|}{ Non septate } & \multicolumn{1}{c|}{$\%$} \\
\hline 1. & Penicillium $(\mathrm{n}=10)$ & 11.1 & Rhizopus(n=18) & 45 \\
\hline 2. & Aspergillus(n=39) & 43.3 & Mucor(n=12) & 30 \\
\hline 3. & Fusarium $(\mathrm{n}=41$ & 45.5 & Absidia(n=4) & 10 \\
\hline 4. & - & - & Curvularia(n=6) & 15 \\
\hline
\end{tabular}

Table3. Distribution of Bacterial isolates

\begin{tabular}{|l|l|l|l|l|l|l|l|l|}
\hline S.No & $\begin{array}{l}\text { Gram positive } \\
\text { cocci }\end{array}$ & $\%$ & $\begin{array}{l}\text { Gram } \\
\text { negative cocci }\end{array}$ & $\%$ & $\begin{array}{l}\text { Gram positive } \\
\text { bacilli }\end{array}$ & \% & $\begin{array}{l}\text { Gram negative } \\
\text { bacilli }\end{array}$ & $\%$ \\
\hline 1. & $\begin{array}{l}\text { Strep.pneumoniae } \\
(\mathrm{n}=6)\end{array}$ & 15 & $\begin{array}{l}\text { Moraxella } \\
\text { cattarhalis(n=5) }\end{array}$ & 12.5 & $\begin{array}{l}\text { Corynebacterium } \\
(\mathrm{n}=4)\end{array}$ & 10 & $\begin{array}{l}\text { Pseudomonas } \\
(\mathrm{n}=9)\end{array}$ & 22.5 \\
\hline 2. & $\begin{array}{l}\text { Staph.aureus } \\
(\mathrm{n}=4)\end{array}$ & 10 & Neissera $(\mathrm{n}=3)$ & 7.5 & - & - & $\begin{array}{l}\text { Enterobacter } \\
(\mathrm{n}=1)\end{array}$ & 2.5 \\
\hline 3. & $\begin{array}{l}\text { S.epidermidis } \\
(\mathrm{n}=2)\end{array}$ & 5 & - & - & - & - & Klebsiella $(\mathrm{n}=3)$ & 7.5 \\
\hline 4. & - & - & - & - & - & - & Esch.coli $(\mathrm{n}=1)$ & 2.5 \\
\hline 5. & - & - & - & - & - & - & Proteus $(\mathrm{n}=2)$ & 5 \\
\hline
\end{tabular}

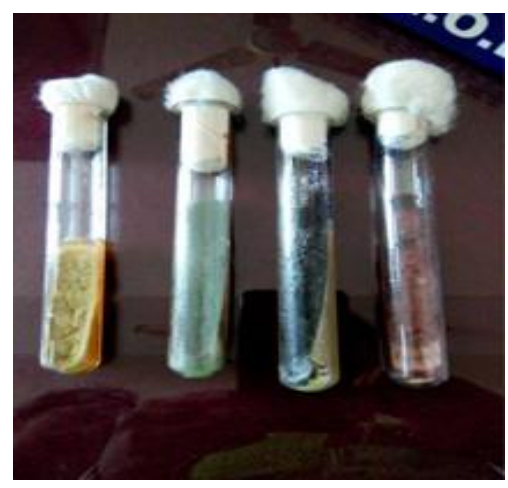

Macroscopic Picture of Fungal cultures on SDA slant 


\section{DISCUSSION}

In our study, we have obtained data that reveals trauma as the major cause of corneal ulcer. 208/ 282 (73.7\%) were cases of traumatic corneal ulcer. This is in concordance with a hospital based study from West Bengal which revealed ocular trauma as the most common predisposing factor for the development of microbial keratitis (82.9\%). ${ }^{[8]} \mathrm{A}$ study from south India also showed corneal injury as the cause of infectious keratitis $(70.88 \%)$. ${ }^{[9]}$ In this study we obtained fungi as the major cause of traumatic corneal ulcer (130/208-62.5\%) which is similar to other studies. On analysis of the history of trauma, majority (102/130-78.4\%) were from agriculture background with history of trauma from organic matter. This data is similar to a hospital based study on epidemiological profile of fungal keratitis were they stated agriculture related ocular trauma was the principal cause of mycotic keratits $(70.3 \%)$.

Among fungal isolates $\mathrm{KOH}$ revealed $69.2 \%$ with septate hyphae and $30.7 \%$ with non septate hyphae. Fusarium was the most common organism $(n=41-45.5 \%)$ followed by Aspergillus $(n=39-43.3 \%)$ and Penicillium ( $\mathrm{n}=10-11.1 \%$ ). This is similar to the study conducted by Srinivasan, Gonzales et al were they isolated Fusarium as the most common fungal isolate with a percentage $47.1 \%$. ${ }^{[11]}$ In our study among the various bacterial pathogens, we obtained Gram negative bacilli $(\mathrm{n}=16)$ as the most common pathogen followed by Gram positive cocci $(n=12)$, Gram negative cocci $(n=8)$ and Gram positive bacilli(n=4).Two different studies from 1997 and 2002 at Aravind eye hospital from Thirunelveli and Madurai identified Streptococcus pneumonia as the most common bacterial pathogen followed by Pseudomonas aeruginosa. ${ }^{[11,12]}$ In our study we have obtained Pseudomonas aeuroginosa as the most common bacterial isolate followed by Streptococcus pneumoniae.

The present study on traumatic corneal ulcer cases in a tertiary care hospital reveals fungi as the major pathogen than bacteria. Among the various fungal and bacterial pathogens the predominant one was Fusarium and Pseudomonas aeruginosa. There is a shift from Streptococcus pneumoniae to Pseudomonas aeruginosa greatly changing the treatment options.

Organisms like Neisseria and Moraxella, which were negligible, has increased to an accountable etiology. These difference in causative organisms in microbial keratitis are clinically important because they influence the initiation of therapy and thus for the prevention of corneal blindness.

\section{REFERENCES}

[1] Garg P, Krishna PV, Stratis AK, Gopinath U. The value of corneal transplantation in reducing blindness. Eye (Lond) 2015;19:1106-14

[2] Garg P, Rao GN. Corneal Ulcer: Diagnosis and Management. Community Eye Health 2017: 12: 21-24

[3] Agarwal V, Biswas J, Madhavan HN, Maggat G, Reddy MK, Saini JS, Srinivasan M. Current perspectives in Infwctious Keratitis. Indian J Ophthalmol 20144; 42: 171-191

[4] Upadhyay MP, Karmacharya PC, Koirala S, Tuladhar NR, Bryan LE, Smolin G, Whitcher JP. Epidemiologic characteristics, predisposing factors, and etiologic diagnosis of corneal ulceration in Nepal.Am J Ophthalmol. 2003 Jan 15;111(1):92-99.

[5] Katz NN, Wadud SA, Ayazuddin M. Corneal ulcer disease in Bangladesh. Ann Ophthalmology 2018; 94: 1662-1668.

[6] Mahajan VM. Ulcerative keratitis: an analysis of laboratory data in 674 cases. J OculTherSurg 2016; 4: 138141.

[7] Carmichael TR, Wolpert M, Koornhob HJ. Corneal ulceration at an urban African hospital. $\mathrm{Br} \quad \mathrm{J}$ Ophthalmol 185; 69: 920-26.

[8] Basak SK, Basak S, Mohanta A, Bhowmick A. Epidemiological and microbiological diagnosis of suppurative keratitis in gangetic West Bengal, eastern India. Indian J Ophthalmol 2005;53:17-22

[9] BharathiMJ,Ramakrishnanr, Meenakshi R, Padmvathy S, Shivakumar C, Srinivasan M. Microbial keratitis in South India: Influence of risk factors, climate and geographical variation. Ophthalmic Epidemiol 2007; 14:61-9

[10] Saha S, Banerjee D, Khetan A, Sengupta J. Epidemiological profile of fungal keratitis in urban population of West Bengal, India. Oman J Ophthalmol 2009; 2:114-8.

[11] Srinivasan M, Gonzales CA, George C, Cevallus V, Mascarenhas JM, Asokan B, Wilkins J, Smolin G, Whitcher JP. Epidemiology and aetiological diagnosis of corneal ulceration in Madurai, South India. Br. J Ophhalmol 2017; 81: 965-971. 
[12] MJ Bharathi, R Ramakrishnan, S Vasu, Meenakshi, R Paliappan. Aetiological diagnosis of Microbial keratitis in South India - Study of 1618 cases. Indian J Med Microbiol. 2002 Jan-Mar;20(1):19-24.

Citation: Dr Shreeram Astic Deshpande, et.al (2020). "A Prospective Study of Bacterial and Fungal Keratitis in a Tertiary Care Medical College Hospital in Kerala ". International Journal of Research Studies in Microbiology and Biotechnology (IJRSMB), vol. 6, no. 3, pp. 1-4, 2020. Available: DOI: https:// doi.org/ 10.20431/2454-9428. 0603001

Copyright: (C) 2020 Authors. This is an open-access article distributed under the terms of the Creative Commons Attribution License, which permits unrestricted use, distribution, and reproduction in any medium, provided the original author and source are credited. 